\section{Molecular Syndromology}

Mol Syndromol 2015;6:55-57

DOI: $10.1159 / 000381081$
Accepted: February 9, 2015

by M. Schmid

Published online: March 26, 2015

\title{
Gene Fusion due to Chromosome Misconnection May Seriously Affect Your Health
}

After observations of abnormal metaphases in sea urchin eggs, Theodor Boveri speculated that the occasional appearance of an abnormal nuclear division in normal tissue may provide a plausible explanation for the production of a malignant tumor or other abnormal phenotypes [Boveri, 1914]. In his view, malignant tumors may be driven to unrestrained proliferation as the result of certain abnormal chromosome constitutions. In this way, Boveri [1914] laid the groundwork for thorough cytogenetic investigations of both the germline and tumor cells. He admitted that 'a hypothesis can be of value only if it leads to targeted new research and, above all, to new experimental investigations'. His work certainly did, and generated, among others, the 'Cancer Genome Anatomy Project' of the National Cancer Institute in Rockville, Md., USA. Analyzing the data in this resource, Mitelman et al. [2007] discovered that genome rearrangements in all forms of cancer had resulted in the formation of 358 gene fusions, which affected 337 genes. In the human germline, gene fusions were also found, albeit as extremely rare events resulting from copy number variations and complex chromosome rearrangements [Nothwang et al. 2001; Yue et al., 2005; Mansouri et al., 2006; Borsani et al., 2008; Backx et al., 2011; Eykelenboom et al., 2012; Holt et al., 2012; Di Gregorio et al., 2013; Malli et al., 2014; Rippey et al., 2013; van Heesch et al., 2014; Bertelsen et al., 2015]. Hence, one could argue that gene fusions, resulting from chromosome rearrangements and occurring in both somatic cells and in the germline, would be such a type of abnormal chromosome constitution as hypothesized by Boveri [1914].

Reanalyzing data from a previous study, van Heesch et al. [2014] discovered that in one patient a chromothripsis event had led to a genomic rearrangement in which 2 genes, DYPD1 and ETV1, were juxtaposed [Kloosterman et al., 2012; van Heesch et al., 2014]. By RT-PCR, they showed that this produced a fusion transcript, which was expressed in peripheral blood lymphocytes. A second chromothripsis event caused a fusion of exon 1-11 of FOXP1 with an unknown genomic element. The truncated N-terminal remnants of ETV1 and of FOXP1 showed reduced expression. Transfected into HEK293 cells, the DYPD1-ETV1 fusion transcript did not produce a stable and functional protein. This suggests that the patient's phenotypes were not caused by the fusion transcript, but possibly due to other gene disruptions or gene losses [Poot et al., 2011].

The ETV1 gene is a frequent partner in gene fusions in prostate cancer [Gasi Tandefelt et al., 2014]. Therefore, the authors compared a set of 552 de novo germline chromosomal rearrangements, of which two-thirds resulted from chromothripsis, with a comprehensive set of 68,018 breakpoints from rearrangements in cancer cells [van Heesch et al., 2014]. Between the de novo germline events and the cancer breakpoints, they found an overlap of 13 breakpoints in 9 genes: RUNX1 (3x), FOXP1 (2x), EBF1 (2×), and GMPS, ETV1, FGFR1, NFIB, VTI1A, HMGA2 (each once). This overlap prompted the authors to hypothesize that germline rearrangements may also predispose to malignant disease. For instance, patients with germline disruptions of RUNX1 may develop hematological malignancies later in life [Buijs et al., 2012]. In this way, the 'mutator hypothesis' of cancer development is extended to also include genomic rearrangements [Fox et al., 2013]. In addition, these findings appear to substantiate the hypothesis Boveri [1914] has put forward a century ago. 
Bleeker et al. [2014] identified 11 syndromes with more than 100 individuals involving microtia and 26 syndromes with hypospadias, in which tumors were found at the same body sites as the major and minor characteristics of the syndromes. This suggests that tumors in patients with malformation syndromes may be explained by abnormal functioning of the same gene that has caused the malformation syndrome. The autosomal recessive disorder Werner Syndrome (WRN), in which patients suffer from a defect in proliferative homeostasis of mesenchymal tissues leading to phenotypes of premature ageing and an increased risk of mesenchymal tumors, also fits the pattern observed by Bleeker et al. [2014] and Epstein et al. [1966]. In addition, this syndrome may provide a mechanistic link between germline and somatic genome rearrangements. Female WRN patients show reduced fertility, while males are completely azoospermic.
Somatic cells from WRN patients show a typical and diagnostic variegated chromosomal translocation mosaicism and spontaneous deletion formation [Salk et al., 1981; Fukuchi et al., 1989]. Absence of the WRN-encoded $3^{\prime}-5^{\prime}$ helicase $-3^{\prime}-5^{\prime}$ exonuclease causes a reduction in recombinational repair, which results in hypersensitivity to DNA cross-linking and double-strand breaks provoking agents [Ogburn et al., 1997; Poot et al., 1999, 2001, 2002, 2004; Dhillon et al., 2007; Su et al., 2014]. In tumor cells, silencing WRN expression by RNA interference induces a mitotic catastrophe and eventually cell death, without affecting normal cells [Futami and Furuichi, 2015]. The studies of van Heesch et al. [2014], Bleeker et al. [2014] and Futami and Furuichi [2015] will certainly generate hypotheses that may lead to targeted new research, and above all, to novel approaches in cancer therapy.

Martin Poot

\section{References}

Backx L, Seuntjens E, Devriendt K, Vermeesch J, Van Esch H: A balanced translocation $\mathrm{t}(6 ; 14)$ (q25.3;q13.2) leading to reciprocal fusion transcripts in a patient with intellectual disability and agenesis of corpus callosum. Cytogenet Genome Res 132:135-143 (2011).

-Bertelsen B, Melchior L, Jensen LR, Groth C, Nazaryan L, et al: A t(3;9)(q25.1;q34.3) translocation leading to OLFM1 fusion transcripts in Gilles de la Tourette syndrome, OCD and ADHD. Psychiatry Res 225:268275 (2015).

-Bleeker FE, Hopman SM, Hennekam RC: Cooccurrence in body site of malformations and cancer. Eur J Med Genet 57:480-485 (2014).

-Borsani G, Piovani G, Zoppi N, Bertini V, Bini R, et al: Cytogenetic and molecular characterization of a de-novo $t(2 p ; 7 p)$ translocation involving TNS3 and EXOC6B genes in a boy with a complex syndromic phenotype. Eur J Med Genet 51:292-302 (2008).

Boveri T: Zur Frage der Entstehung maligner Tumoren. (Jena, Fischer 1914).

- Buijs A, Poot M, van der Crabben S, van der Zwaag B, van Binsbergen E, et al: Elucidation of a novel pathogenomic mechanism using genome-wide long mate-pair sequencing of a congenital $t(16 ; 21)$ in a series of three RUNX1mutated FPD/AML pedigrees. Leukemia 26 : 2151-2154 (2012).

Dhillon KK, Sidorova J, Saintigny Y, Poot M, Gollahon K, et al: Functional role of the Werner syndrome RecQ helicase in human fibroblasts. Aging Cell 6:53-61 (2007).
Di Gregorio E, Bianchi FT, Schiavi A, Chiotto AM, Rolando $\mathrm{M}$, et al: A de novo X;8 translocation creates a PTK2-THOC2 gene fusion with THOC2 expression knockdown in a patient with psychomotor retardation and congenital cerebellar hypoplasia. J Med Genet 50: 543-551 (2013).

Epstein CJ, Martin GM, Schultz AL, Motulsky AG: Werner's syndrome a review of its symptomatology, natural history, pathologic features, genetics and relationship to the natural aging process. Medicine (Baltimore) 45:177221 (1966)

Eykelenboom JE, Briggs GJ, Bradshaw NJ, Soares DC, Ogawa F, et al: A $t(1 ; 11)$ translocation linked to schizophrenia and affective disorders gives rise to aberrant chimeric DISC1 transcripts that encode structurally altered, deleterious mitochondrial proteins. Hum Mol Genet 21:3374-3386 (2012).

Fox EJ, Prindle MJ, Loeb LA: Do mutator mutations fuel tumorigenesis? Cancer Metastasis Rev 32:353-361 (2013).

Fukuchi K, Martin GM, Monnat RJ Jr: Mutator phenotype of Werner syndrome is characterized by extensive deletions. Proc Natl Acad Sci USA 86:5893-5897 (1989).

Futami K, Furuichi Y: RECQL1 and WRN DNA repair helicases: potential therapeutic targets and proliferative markers against cancers. Front Genet 5:441 (2015).

Gasi Tandefelt D, Boormans J, Hermans K, Trapman J: ETS fusion genes in prostate cancer. Endocr Relat Cancer 21:R143-R152 (2014).

Holt R, Sykes NH, Conceição IC, Cazier JB, Anney $\mathrm{RJL}$, et al: CNVs leading to fusion transcripts in individuals with autism spectrum disorder. Eur J Hum Genet 20:1141-1147 (2012).
Kloosterman WP, Tavakoli-Yaraki M, van Roosmalen MJ, van Binsbergen E, Renkens I, et al: Constitutional chromothripsis rearrangements involve clustered double-stranded DNA breaks and nonhomologous repair mechanisms. Cell Rep 1:648-655 (2012).

-Malli T, Duba HC, Erdel M, Marschon R, Kranewitter W, et al: Disruption of the ARID1B and ADAMTS6 loci due to a $(5 ; 6)(\mathrm{q} 12.3 ; \mathrm{q} 25.3)$ in a patient with developmental delay. Am J Med Genet A 164A:3126-3131 (2014).

Mansouri MR, Carlsson B, Davey E, Nordenskjöld $\mathrm{A}$, Wester $\mathrm{T}$, et al: Molecular genetic analysis of a de novo balanced translocation $\mathrm{t}(6 ; 17)(\mathrm{p} 21.31 ; \mathrm{q} 11.2)$ associated with hypospadias and anorectal malformation. Hum Genet 119:162-168 (2006).

Mitelman F, Johansson B, Mertens F: The impact of translocations and gene fusions on cancer causation. Nat Rev Cancer 7:233-245 (2007).

-Nothwang HG, Kim HG, Aoki J, Geisterfer M, Kübart $S$, et al: Functional hemizygosity of PAFAH1B3 due to a PAFAH1B3-CLK2 fusion gene in a female with mental retardation, ataxia and atrophy of the brain. Hum Mol Genet 10:797-806 (2001).

-Ogburn CE, Oshima J, Poot M, Chen R, Hunt KE, et al: An apoptosis-inducing genotoxin differentiates heterozygotic carriers for Werner helicase mutations from wild-type and homozygous mutants. Hum Genet 101:121-125 (1997).

Poot M, Gollahon KA, Rabinovitch PS: Werner syndrome lymphoblastoid cells are sensitive to camptothecin-induced apoptosis in Sphase. Hum Genet 104:10-14 (1999). 
Poot M, Yom JS, Whang SH, Kato JT, Gollahon KA, Rabinovitch PS: Werner syndrome cells are sensitive to DNA cross-linking drugs. FASEB J 15:1224-1226 (2001).

Poot M, Gollahon KA, Emond MJ, Silber JR, Rabinovitch PS: Werner syndrome diploid fibroblasts are sensitive to 4-nitroquinoline- $\mathrm{N}$ oxide and 8-methoxypsoralen: implications for the disease phenotype. FASEB J 16:757758 (2002).

Poot M, Jin X, Hill JP, Gollahon KA, Rabinovitch PS: Distinct functions for WRN and TP53 in a shared pathway of cellular response to 1-beta-D-arabinofuranosylcytosine and bleomycin. Exp Cell Res 296:327-336 (2004).
Poot M, van der Smagt JJ, Brilstra EH, Bourgeron $\mathrm{T}$ : Disentangling the myriad genomics of complex disorders, specifically focusing on autism, epilepsy, and schizophrenia. Cytogenet Genome Res 135:228-240 (2011).

Rippey C, Walsh T, Gulsuner S, Brodsky M, Nord AS, et al: Formation of chimeric genes by copy-number variation as a mutational mechanism in schizophrenia. Am J Hum Genet 93: 697-710 (2013).

Salk D, Au K, Hoehn H, Martin GM: Cytogenetics of Werner's syndrome cultured skin fibroblasts: variegated translocation mosaicism. Cytogenet Cell Genet 30:92-107 (1981).
Su F, Mukherjee S, Yang Y, Mori E, Bhattacharya $S$, et al: Nonenzymatic role for WRN in preserving nascent DNA strands after replication stress. Cell Rep 9:1387-1401 (2014).

-van Heesch S, Simonis M, van Roosmalen MJ, Pillalamarri $\mathrm{V}$, Brand $\mathrm{H}$, et al: Genomic and functional overlap between somatic and germline chromosomal rearrangements. Cell Rep 9:2001-2010 (2014).

-Yue Y, Grossmann B, Holder SE, Haaf T: De novo $\mathrm{t}(7 ; 10)(\mathrm{q} 33 ; \mathrm{q} 23)$ translocation and closely juxtaposed microdeletion in a patient with macrocephaly and developmental delay. Hum Genet 117:1-8 (2005). 